International Journal of Engineering \& Technology, $7(2.29)(2018) 527-534$
International Journal of Engineering \& Technology
SPC
Website: www.sciencepubco.com/index.php/IJET
Research paper

\title{
Communication Style and Communication Competence Of President Jokowi
}

\author{
Drina Intyaswati ${ }^{1 *}$, Mansur Juned ${ }^{2}$, Ahmad Zakki Abdullah ${ }^{3}$ \\ ${ }^{I}$ Department Of Communication Science, Universitas Pembangunan Nasional "Veteran” Jakarta \\ ${ }^{2}$ Department Of International Affairs, Universitas Pembangunan Nasional "Veteran" Jakarta \\ ${ }^{3}$ Department Of Communication Science, Universitas Pembangunan Nasional "Veteran” Jakarta \\ *Corresponding Author E-Mail: Nanazain@Gmail.Com
}

\begin{abstract}
This research would like to see the communication style of president jokowi in connection with the disharmony of his ministers in communicating in public. The problem in this research is; (1) How is President Jokowi's communication style in policy making? (2) How is the communication competency of President Jokowi?. The method used in this research is qualitative by using structural discourse analysis. Data were taken from online news especially detik.com and kompas.com, which is the most popular data provider. The results show that the most widely used communication style of president jokowi is controlling style and also others communication style according to an existing situation. Based on the communication made by the president jokowi, he has communication competence that includes the aspects of commitment and confidence, flexibility, empathy, the sensitivity of consequences, and skills obtained from adaptation
\end{abstract}

Keywords: Communication Style; Jokowi; Communication Competence; Discourse Analysis

\section{Introduction}

Humans are born as social beings that cannot be separated from interactions with other humans. Such interactions can take many forms. If the stimulus is given then there will be a response, this is where the communication process occurs. Someone gives a message or information and the other becomes affected by the stimulus it receives so that it responds. Communication can be done verbally, either in spoken or written form. There is also non-verbal communication, which can include body movements, gestures, eye contact, facial expression, and position factors. In this case, there are other contexts that influence the communication process beyond spoken and written utterances. More broadly the things that are outside the messenger will also affect the meaning of messages or information received by the recipient of the message. The meaning of the sent message can also give the message different meaning depending on how the message is delivered. How a person conveys a message has different characteristics, in which communication is called a communication style. The purpose of communicating is that the message conveyed can be received and understood by the recipient of the message, and then the recipient of the message may be affected to do as it is in the message. The ability of a person to convey a message so that messages can be received by the recipient called communication competence. In connection with the communication style and communication competence, in the mass media, there was a polemic about the communication style of President Jokowi, especially when there was a disagreement between ministers of the president Jokowi conducted in public. It becomes interesting when it becomes a question of people how president Jokowi behaves, especially in communicating with his ministers.

Indonesia has various ethnic groups, where it will affect how people communicate. Based on previous research it was found that people have different communication styles influenced by different cultures 1 . In communication, there is also a term of lowcontext and high-context. The different ways of communicating are influenced by cultural differences. Explicit messages are used by people from cultures with low context, they pay little attention to background information (contextual), while people from high context cultures do not rely on direct information and pay more attention to contextual information 2. The explicit and implicit dimensions of one's communication can also be done because of the different purposes of the communication, how to convey the message to be received by the recipient with a specific purpose. The explicit communication style is the person who speaks directly of expressing his feelings, intentions, and desires, while the implicit communication style is the one who speaks verbally with camouflage and conceals his true intentions3.

Communication competence is related to a person's ability to communicate, how he practices his knowledge in communication behavior and expression, both verbally and non-verbally. Previous research has found that communication competence has three dimensions that include self-confidence, self-image, and respectrelational4. In addition, studies that look at Malay communication styles argue that for Malays, their religion will establish their communication5. Other studies recommend that Malay leaders be expected to model their behavior based on their subordinate religious and cultural values, in an effort to win their hearts and minds 6 . It can be seen that one's communication competence can 
be evaluated based on cultural, contextual, and situational dimensions. So the ability of a person to use knowledge about the context or situation in communicating will affect the behavior that arises.

In the Indonesian mass media, especially in early 2017, various issues were raised related to the communication style of President Jokowi. This is related to the statement of several ministers from President Jokowi who gave contradictory public statements among them, so it is questioned the existence of Jokowi as president in managing his subordinates, especially in attitude and communication. Based on the emerging news then formulated a problem in this research is; (1) how is President Jokowi's communication style in policy making ?. (2) how is the communication competency of President Jokowi ?. This research was conducted in the hope to know how the communication style of President Jokowi in communicating his policy, and knowing how communication competence is owned.

\section{Literature Review}

\subsection{Understanding Discourse Analysis and Macrostruc- tural Approach}

In the perspective of critical discourse is understood as the use of language as a social practice. Discourse must be understood in three discourse dimensions simultaneously ; discourse, text, and socio-cultural practices 7 . Dimension text includes spoken and written language, discourse practice dimension associated with the production and interpretation of texts, and dimensions of social cultural practices associated with changes in social aspects of society, institutions, and culture, three things help determine the shape and meaning of a discourse.

The discourse analysis examines the relationship between language in the context of its use. To understand a discourse to consider all the elements involved in the use of the language 8 . In macrostructural, discourse analysis focuses on the outline of the composition of the global discourse to understand the text as a whole. Besides attention to the linkages between episodes and paragraphs, are also considered backgrounding and a foregrounding . Macrostructural approach can include textual structure, lexis system, and the context, which is intended as a macrostructural context is the context of the situation and culture 9 .

\subsection{Communication style}

The communication style is a set of interpersonal behavior that use specially in a given situation. The force referred itself can type in the form of verbal or nonverbal words such body language, use of time, and the use of space and distance 10 . While the communication style that we will make references in this study are as follows 11 .

\section{The Controlling Style}

This communication style characterized by the presence of one's will or intention to restrict, coerce and regulate behavior, thoughts, and responses of others. People who use this communication style known as the one-way communicator or one-way communications. Parties are taking controlling style of communication, more focus on the delivery of the message just than their efforts to expect a message. They do not have a sense of interest and concern to share the message. They do not have a sense of interest and attention on the feedback unless feedback or feedback are used for their personal interests. The one-way communicators are not worried by the negative views of others, but instead try to use the authority and power to force others to comply with his views. The messages came from the one-way communicator, not trying to 'sell' the idea to be discussed together, but rather on efforts to explain to others what it does. The controlling style is often used to persuade others to work and act effectively, and generally in the form of criticism.

\section{The Equalitarian Style}

The important aspect of this communication style is their common ground. The equalitarian style of communication is marked by the entry into force of the current deployment of verbal messages spoken and written two-way (two-way traffic of communication). In this communication style, communication acts done openly. That is, every member of the organization can express ideas or opinions in a relaxed atmosphere, relaxed and informal. In such an atmosphere, allowing each member of the organization to reach an agreement and mutual understanding. People who use the equalitarian styles are people who have a high caring attitude and the ability to maintain a good relationship with others both in the private context and within the scope of the employment relationship. The equalitarian style will facilitate acts of communication in the organization, because this style is effective in maintaining empathy and cooperation, especially in a situation to take a decision on a complex problem. These communication styles guarantee the actions sharing of information among the members of an organization.

\section{The Structuring Style}

This structured communication styles, utilizing verbal messages in writing or verbally in order to establish a command to be executed scheduling tasks and jobs as well as the organizational structure. The sender of the message more attention to his desire to influence others by the way share information about the organization's objectives, work schedules, rules and procedures that apply to the organization. The Bureau of Business Research of Ohio State University, find the dimensions of effective leadership, which they named Initiation or Initiating Structure. They explained that the initiator efficient structures are the ones who are able to plan verbal messages in order to further strengthen the goals of the organization, assignment framework and provide answers to questions that arise 12

\section{The Dynamic Style}

This dynamic communication style has aggressive tendencies because the sender understands that working environment oriented to the action ( action-oriented). The dynamic style of communication is often used by campaigners or supervisor who brings salespeople (salesmen or saleswomen). The main objective of this aggressive communication styles are stimulated workers or employees to work faster and better. This is an effective communication style used in addressing issues that are critical, but with the requirement that the employees or subordinates have sufficient ability to address these critical issues.

\section{The Relinquishing Style}

This communication style reflect the willingness to accept suggestions, opinions or ideas of others, rather than a desire to give orders, though the sender of the message has the right to command and control others. The messages in this communication style will be effective when the sender is working with people who are knowledgeable, experienced, conscientious and willing to be responsible for all tasks or jobs.

\section{The Withdrawal Style}

Consequences that arise if the withdrawal style used is weakening acts of communication meaning there is no desire from the people who use this style to communicate with other people because there are some problems or interpersonal difficulties faced by the communicator. In the description of the concrete is when someone says: "I do not want to be involved in this issue". This statement means that he tried to escape from responsibility, but also indicate a desire to avoid communicating with others. Therefore, this style is not proper to be used in the context of organizational communication.

The general picture obtained from the above description is that the equalitarian style of communication is a communication style that is ideal. While the other three communication styles: structuring, 
dynamic and relinquishing can be used strategically to generate beneficial effects for the organization. And the last two communication styles: controlling and withdrawal have a tendency impede the ongoing fruitful interaction. Of the six styles of communication will be used as reference and materials boards in this research

\section{Factors that influence communication style}

There are seven components identified as the thing that can reflect or give views on the interaction of each individual.

\section{Physical Condition}

Physical conditions influence the style of communication when someone communicates. As well as the communication activities carried out with minimal capacity in face to face, it will result in discomfort and lack of certainty between the sender and the recipient. Moreover, it can lead to inconsistency or uncomfortable between the two sides.

\section{Role}

Own perception of our role (as customers, friends, superiors) and the role of other communicators affect how we interact. Everyone has different expectations of their own role and others, and thus they will often make the communication between each other.

\section{The Historical Context}

History affects every interaction. The history of nations, spiritual traditions, companies, and communities can easily affect how we perceive each other, thereby affecting communication styles.

\section{Chronology}

One's communication style fits into a series of interaction events that influence the choice. It will make a difference, if it is the first time someone interacts with something or the tenth time, if a person's past interactions have been successful or not pleasant. Then it will make a difference to one's communication style.

\section{Language}

The language we use, "version" of the language that we speak, for example, Aussie, English or American English version and our fluency in the language. All play a role in a person's communication style. One's communication style in English means that people who used to speak Japanese do not understand him, and this ability will impose limits on a person to fully participate in and influence the direction of the conversation.

\section{Relationship}

How well do we know the other person, and how much we like or trust him. This will affect how we communicate. In addition, we develop a certain relationship patterns over time often giving a cumulative effect on the next interaction between relational partners.

\section{Constraints}

The method a person uses to communicate (for example, some people hate e-mail or phone call) and the time we have available only to interact with the above method. Type constraints will affect the way we communicate.

\section{Barriers in Communication Style}

\section{Technical Barriers limitation of facilities and communica- tion equipment.}

In terms of technology, technical barriers are diminishing with their new findings in the field of communications and information technology advances, so that the communication channel is reliable and efficient as a communication medium.

\section{Barriers Semantics}

Semantic interference is a bottleneck in the process of conveying meaning or idea effectively. The definition of semantics as the study of meaning, which is expressed through language. Words help the process of reciprocal exchange and understanding mean- ing (communicator and communicant), but it is often mistaken interpretation process. The absence of correlation between symbols (words) and what is symbolized (meaning or interpretation), may result in the word used is interpreted very differently from what was intended actually. To avoid any such communications, a communicator must choose words that are appropriate to the characteristic's of the recipient, and see the possibilities of interpretation of the words he uses.

3. Human Barriers / obstacles that comes from individual differences in humans. Occur because of factors, differences in age, emotions and personal prejudices, perceptions, skills or incompetence, the ability or inability of a person with sensory equipment.

There are four fundamental communication styles: Intuitive, Analytical, Functional, and Personal 13. There is no communication style is inherently better than another. But using the wrong style for a particular audience or a thousand persons can spell trouble and shuts down listening. The main difference that separates the four communication styles is depending on how someone communicates with emotions or with data. Another difference is based on whether someone communicates in a linear way, example someone like to start with $\mathrm{A}$ then $\mathrm{B}$ then $\mathrm{C}$, all the way to $\mathrm{X}$, or in a freeform way, example someone like to jump over most of the details and jump right to $\mathrm{X}$ ).

\section{The Intuitive Communicator}

Intuitive communicator, someone that like the big picture, he avoids getting bogged down in details, and cuts right to the chase. This style doesn't need to hear things in perfect linear order, easily skip right to the end point with prefer instead a broad overview. Quick and to the point is one big plus of having an Intuitive communication style. He doesn't need too many details and think outof-the-box and also comfortable with big ideas. The weakness of Intuitive communication style is that may risk missing an important point when there is no have enough patience in a situation that actually requires getting into details. Intuitive communicators have difficulty dealing with Functional communicators.

\section{The Analytical Communicator}

Analytical communicator, someone that like real numbers, hard data and he tend to disagree of people who aren't in a base of the facts and data. He doesn't like vague language but typically with very specific language. This style often has little patience for lots of emotional words in communication. Look at issues logically and dispassionately is one big plus of having an Analytical communication style. He likes communication to be fairly unemotional. Others tend to see this style as having informational expertise and high levels of data. The weakness of Analytical communication style is that may strike certain people as being unfeeling or cold, especially when interacting with people like Personal communicators (who tend to like warm relationships).

\section{The Functional Communicator}

Functional communicator, someone that like process, timelines, detail, and well-thought-out plans. He nothing gets missed because he communicates things in a step-by-step. This style contrary to the Intuitive communicators, who like to jump right to the end skip all the detail. Nothing gets missed and hits all the details is one big plus of having a Functional communication style. This style to be fit as a implementer, because loving of process and detail. The weakness of Functional communication style is that may risk losing the attention of the audience.

\section{The Personal Communicator}

The Personal communicator, someone that value connection and emotional language. He finds value in assessing how people feel and think. This style to be a good listener and diplomat, that can smooth over conflicts. Build deep personal relationships with others is one big plus of having a Personal communication style. This style to be fit as the 'glue' that holds groups together. The 
weakness of Personal communication style is that may be derided as 'touchy-feely.'

\subsection{Communication Competence}

Communication competence is the demonstration of communication knowledge by way of the appropriate use of communication skills 14. Competent communication consists of behaviors that are regarded as effective and appropriate 15 . Effective communication can be accomplished by individuals through adaptation, these can be seen in four patterns of behavior 16. First, behavioral matching happen when behaviors of both interactants are like one another. These patterns include interactional synchronicity, mirroring, reciprocity, and convergence. Complementarity is there are different of each individual's patterns from the other but complements the other in some ways. Divergence, there is dissynchrony, happen when a pattern dissimilar from at least one of the interactants, where there is an evident lack of coordination between the interactants. Compensation happen when interactants have patterns behavior that opposite but avoidance. appropriate and effective use of knowledge and skills. An appropriate and effective use of knowledge and skills obtained through adaptation to a particular communication situation.

Competence lies within the cognitive domain while skill is demonstrated within the psychomotor domain17. In view of this, competence has both knowledge and skills component. Between competence and skill there is a different, that competence is the use of the appropriate application of that knowledge in adapting to a situation, if someone is good at adapted to a particular situation and demonstrated based on the appropriate knowledge it is said that someone has a skill, and it is applied in a spesific behavior. Communication competence is relational competence involves five assumptions : that are contextual, judged as a continuum of effectiveness and appropriateness, functional, appropriate and effective, and an interpersonal impression formed between the communicators 18. Another examination of the competence criteria, there are six qualities that related to interpersonal relations: efficiency, fidelity, satisfaction, appropriateness, effectiveness, and ethics 18. From some theoretical concepts of communication competence above, a common seem to run through the theories is that communication is a psychological as well as a physiological process, at the minimum, and cultural make-up at the best 14 . Although communication competence will not have one set meaning, these could mean almost anything related to communication effectiveness 19 .

Based on the expositions and viewpoints and of these concepts, four elements largely emerge: skill, knowledge, adaptation, and appropriateness. So, we can say that one's adaptation of a communication situation associated with communication competence, equipped by demonstrating skills in appropriating knowledge relevant to the communication context and situation. Someone has to have the communication knowledge to be competent, in order to develop the appropriate skills hereinafter can be used to adapt to situational demands.

Competence of communication is the ability to deliver news and promote the achievement of social objectives 20. Communicators trying to straighten each other so aimlessly productive dialogue, smooth, and often popular. Competence is the attitude and ability are important, include: (1) Commitment and confidence (Commitment and good faith). (2) Empathy: the ability to see the situation from the perspective of others. (3) Flexibility: the ability of communicators to develop a range of communication skills. (4) Sensitivity to Consequences: choice of communication possibilities to give success in one situation and several unsuccessful in others. Based on experience, communication competence will gain skills to better understand the potential effects of various skills in complex situations. (5) adaptness : with the experience we have, we will have the skills. Effective communication partly linked to how we respond spontaneously. The time, the choice of words, emphasis, and rhythm all should be well integrated and spontaneously, then communication skills will be obtained.

\section{Methodologies}

This type of research is a qualitative research with macrostructural discourse analysis approach. The population in this study is the news about the communications by President Jokowi as well as policies in the country and abroad, where the medium used is the online media. Sampling using judgment sampling method, with selected samples are taken from the news News.detik.com and Kompas.com which are the two most popular news provider (ALEXA version per February 18, 2015). Data were collected from March to April 2017..

\section{Results and Findings}

\section{Here are the issues taken from detiknews.com and kompas.com}

\section{Issues on electronic identity card (e-KTP) corruption}

This news entitled "Jokowi's Satire on Plastic e-KTP". President Jokowi apologizes for recording e-ID card data is still not completed. Coupled with the existence of corruption cases that add to the length of existing problems. "To be known, in Ministry of Internal Affairs that handles e-ID card problem, the employee who called the Corruption Eradication Commission (KPK) there are 32 people, back and forth, so if there is a lack of form and other it is the impact of e-ID card problem," said Jokowi. Jokowi also regretted that the project that spent almost IDR 6 trillion only managed to move the type of paper to plastic ID cards. "So we apologize if there is still a problem because it is supposed to be sophisticated and quickly finished. It took IDR 6 trillion, and it is only ID card that changed from paper to be plastic, that's all," firmly Jokowi. Responding to the existence of a minister of law as a witness in the case of e-KTP corruption, Jokowi stated "Principle of a presumption of innocence. Let this go into a legal entity." Yasonna as Minister of law was called KPK as a witness, he called received USD 84 thousand of corruption e-ID card while sitting in Commission II of House of Representative (DPR)

\section{Human Rights Issues}

This news is titled "Sumarsih said: Jokowi More Inhuman than the President Before." Sumarsih claimed to have sent three times to meet President Jokowi. She wanted to speak directly to the President about the Semanggi I Tragedy that took his son's life. However, there has never been a clear answer from the presidency regarding the President's willingness to meet. "Answer never existed, the staff of the Cabinet Secretariat said, Mr. President has not scheduled to receive our families of victims," said Sumarsih. Sumarsih said that actually, it does not matter if she does not meet Jokowi, the most important, Jokowi and his government can solve the case that killed his son with justice. Sumarsih also compared the attitude of President Jokowi with previous presidents. According to him, previous presidents are much better because they want to accept the victims of past human rights violations. Sumiarsih considers that President Jokowi more inhuman than previous presidents.

\section{Issues on Investment from Saudi Arabia}

This news raises the title "Saudi Investment to China IDR $870 \mathrm{~T}$, Jokowi: We Must Introspect." During a visit to China the same month with a visit to Indonesia, King Salman of Saudi Arabia signed an investment agreement almost 10 times that invested in Indonesia. "Investment in China is big, it should be our introspection, why we cannot achieve more amount," said Jokowi. "Perhaps the legal certainty, it still needs to be improved, many things are improved, I think this is our criticism and introspection materials," continued Jokowi. "Well, even though I was already in the rain and was driving around the palace for King Salman. This is a bit 
of my disappointment," said Jokowi. Jokowi's jealousy was conveyed to one of the Prince of Saudi Arabia. To the prince, President Jokowi expressed his hope that Saudi investment in Indonesia is even higher. If Indonesia makes a serious correction, Jokowi is optimistic that investors prefer Indonesia compared to other countries.

\section{The issue of ministerial targets}

This news entitled "Jokowi to the Minister of Agrarian Affairs: If the Target Unreachable, Can be Changed." On one occasion Jokowi was a bit sarcastic to Minister of Agrarian Affairs, Sofyan Djalil. "Redistribution of assets and agrarian reform currently has 126 million plots of land, of which only 46 million are already certified, meaning that 60 percent more land has not been certified," Jokowi said. "I work always on target, and the minister of agrarian never asks me if the target is too big, it's ministerial business, I want the target to be resolved, otherwise the case will be different, the minister can be replaced," said Jokowi. Jokowi said most of the land that has not certificate exist in the village or owned majority of poor people who do not have the cost to take care of it. Jokowi admitted, has set the land certification program this year as many as 5 million certificates, the next year as many as 7 million certificates, and the next year 9 million certificates. Currently, said Jokowi, the Minister of Agrarian can only issue 400 certificates within a year. According to him, in eradicating the gap, it should immediately accelerate the issuance of land certificates for the poor. This is related to people who have difficult access to capital because they have no guarantee, in any country the land certificate is granted first. "continued Jokowi.

\section{The Issue of ease of investment}

This news is titled "Inaugurated Mitsubishi Factory, Jokowi: Investments Do not Get Difficult". "I often say that investment is important, so investors should not be complicated so that the economy will move, there will be economic growth in Indonesia, so that many of our people will get jobs because the investment opens employment, meaning that unemployed can work. " said Jokowi. Jokowi said, the inaugurated Mitsubishi plant can absorb 3,000 workers. Jokowi also said, "Indonesia is increasingly competitive for the automotive industry, and the automotive industry growth averages $10 \%$ more, I believe that there will be more automotive investment coming to Indonesia because the market is big," he said. "With more investment, more jobs are available," added Jokowi. "Human Resource is one of the economic policy launched by the government, we will take vocational and entrepreneurship education," he said. The government will continue to issue policies of job matching between vocations and industry. Jokowi also reminded, the investment in the field of industry, is expected to transfer the technology and knowledge.

\section{The issue of investigation by foreign journalists}

This news raise the title "Investigation of Allan Nairn offensive to Indonesian Army (TNI), This Jokowi said." Journalist from the United States Allan Nairn wrote the results of an investigation that mentions the involvement of the TNI in an effort to defeat the government of President Jokowi. Jokowi's response to the results of the investigation, "Who wrote it? Yes asked Allan Nairn, why ask me, ask to the writer," said Jokowi. Allan Nairn's writing was re-uploaded by the editor of Tirto.id. The TNI strongly denied the writing and called it as hoax. Even the TNI is considering taking legal action against the Tirto.id upload.

\section{Budgeting Issues}

This news entitled "Warning Jokowi to the Minister Until the Governor about Budgeting". "I remind you that for years our budget has never been focused. Our planning is never focused and has no clear priorities, "Jokowi said, only three priority programs are set in a year, but if the leaders find it difficult, then it is possible to have five priority programs. According Jokowi, all must be changed for the realization of appropriate shopping target. This, of course, also facilitates the accountability of the government to the people as the budget executive.

\section{The issue of organizing the Asian Games}

This news is titled "Jokowi Want Asian Games Give Big Benefits to Nations". President Jokowi held a limited meeting of preparations for the 2018 Asian Games. "Therefore, the limited meeting this time I want to get a report on the preparation of the field and I ask for progress in the field really continue to be seen, monitored in detail, in detail how far the progress, whether there are obstacles in the field, and everything continues must be checked, checked and checked again, "said Jokowi. "I want the 2018 Asian Games momentum to provide the greatest benefit for the nation," he continued. "Do not think that it's all built for the Asian Games itself, but we build that infrastructure also for the benefit, the future of our nation especially in sports." "I ask that this opportunity be captured as well as possible, integrated with promotion for the country, also for tourist destinations that have been prepared in several places," he explained.

\section{Issues The focus of Indonesia's development}

This news entitled "3 Main Focus Jokowi to Build Indonesian Economy". "I convey to the minister, we want to focus on infrastructure and investment," said Jokowi. "Second is the integration from the central government down to the village. What I have encountered, there are no irrigation reservoirs for years. In Aceh, I was told by the Governor. There is no harbor road. Third, the focus is to bring in investors." Continued Jokowi. "Our budget is only able to provide IDR 1,500 trillion. Below $30 \%$. Where is the rest? from investment. There is no other way but investment. Getting investors, there is no other way," he explained. In building the infrastructure, Jokowi ensure no loss. For example StateOwned Enterprises (SOEs) when building toll roads, completed development can be sold to build other infrastructure.

\section{The Issue of Letter of Liability}

This news raise the title "Jokowi: If getting Letters of Liability Still Rambling, Please Report to me". President Jokowi mentioned again about letter of liability s that drain the time of Civil Servants (PNS). Jokowi said, now it is better because it only requires two procedures in the completion of the letter of liability. Previously there were dozens of procedures that must be passed. Jokowi also open a chance of complaint for anyone who is still difficult in the completion of the letter of liability. The reason, it is considered very disturbing performance of the government. "I've got a report, now it's only 2 procedures, but if it's still long-winded please send it to me," said Jokowi. Government require civil servants who have high productivity. Therefore, global changes that occur so fast should be offset by Indonesia, especially from the economic side. "In the competition between countries, the key is, we must adjust quickly in many ways," said Jokowi

\section{Issues Attract foreign investors}

This news is titled "Jokowi Asked the National Investment Agency (BKPM) Imitate The Way of India and Vietnam to Attract Investor". President Jokowi asked the National Investment Agency (BKPM) to study the ways in which India and Vietnam attract foreign investors, including making investor-friendly regulations. "The instability of regulation that hampers investment in Indonesia." Jokowi said that overlapping regulation, contradictory between ministries and institutions, and less mature in the making. Industry in Vietnam and India is fast growing because it is not much regulated by its government, very open, does not burden investors with various obligations. National standards created to protect national products but make Indonesian products difficult to export due to their different standards to the international world. Foreign investors are also lazy to enter because the products with different standards that hard to enter other countries.

\section{The issue of the fate of the workers}


This news entitled "When Jokowi Lunch With The Leaders of Labor". President Jokowi took lunch together and talked with the trade union leaders (laborers). Representatives of workers ask the attention of the President related to the issue of state-owned enterprises holding so that later there is a certainty status, career certainty, do not get the salary and do not have layoffs. Also, workers' concerns are related to toll road automation which could impact on layoffs. Responding to workers' aspirations, Jokowi said, "Holding is to strengthen the role of state-owned enterprises in global competition. The process must certainly consider many things, including the interests of workers to stay able to work and have a good career. That is a good input and important to be noticed by our stated-owned enterprises in the framework of holding," said Jokowi.

\section{Jokowi issue at the ASEAN Summit}

This news is titled "Jokowi Discusses North Korean and South China Sea Issues at the ASEAN Summit". At the 30th Summit of the Association of South East Asia Nations (ASEAN), the President of Indonesia Jokowi also mentioned tensions on the Korean Peninsula. "ASEAN should send a strong message to North Korea to comply with all UN Security Council resolutions," said Jokowi. "Stability and peace on the Korean Peninsula must be restored,"
Jokowi continued. Jokowi also mentioned about the South China Sea. "Indonesia invites China to continue to contribute to stability and peace in the South China Sea," said Jokowi. "People-centered people-oriented" should not be used as a jargon but must be implemented. Migrant workers should be protected, ASEAN seafarers should feel safe sailing in ASEAN waters, our small and medium enterprises should continue to be empowered, and ASEAN's human rights should be protected and promoted." said Jokowi.

\section{Issue of Indonesian labor abroad}

This news raises the title "There are TKI Compassing KTKLN Problem, Jokowi Direct Call Nusron". President Jokowi received a rousing welcome when he met Indonesian citizens in Hong Kong. Most of these citizens are migrant workers or Indonesian workers (TKI). One Indonesian migrant worker asked about the existence of a foreign worker card deemed to be difficult for them. Jokowi immediately called the Head of BNP2TKI Nusron Wahid. Her tone was a little higher than before. "I have ordered nothing to hamper our migrant workers, I have already ordered that I will check it in the field," said Jokowi. After hearing Nusron's answer, Jokowi then asks the workers who are complicated to report. So the culprit can be dealt with.

Table 1: Summary Of Macrostructural Discourse Analysis

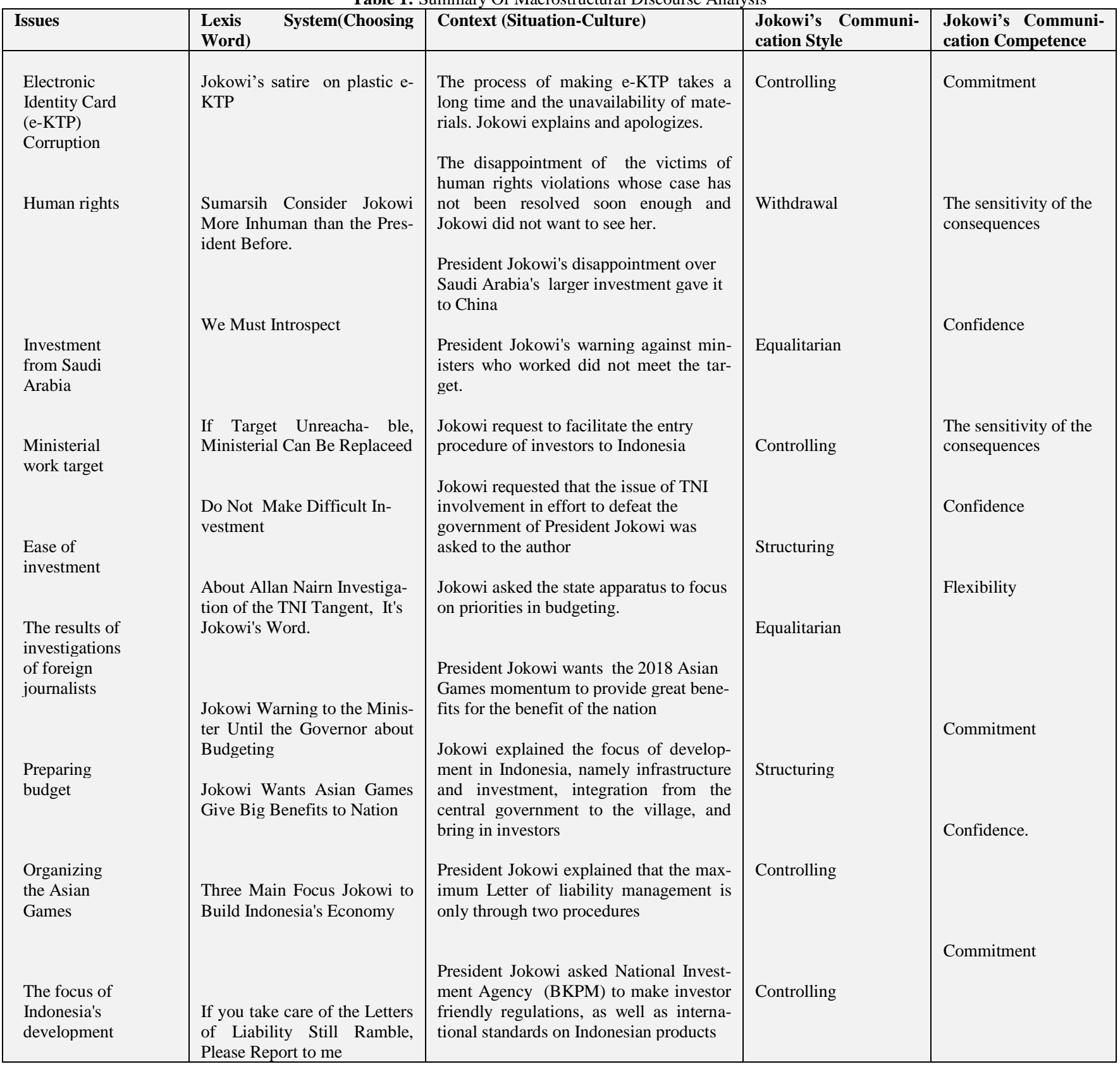




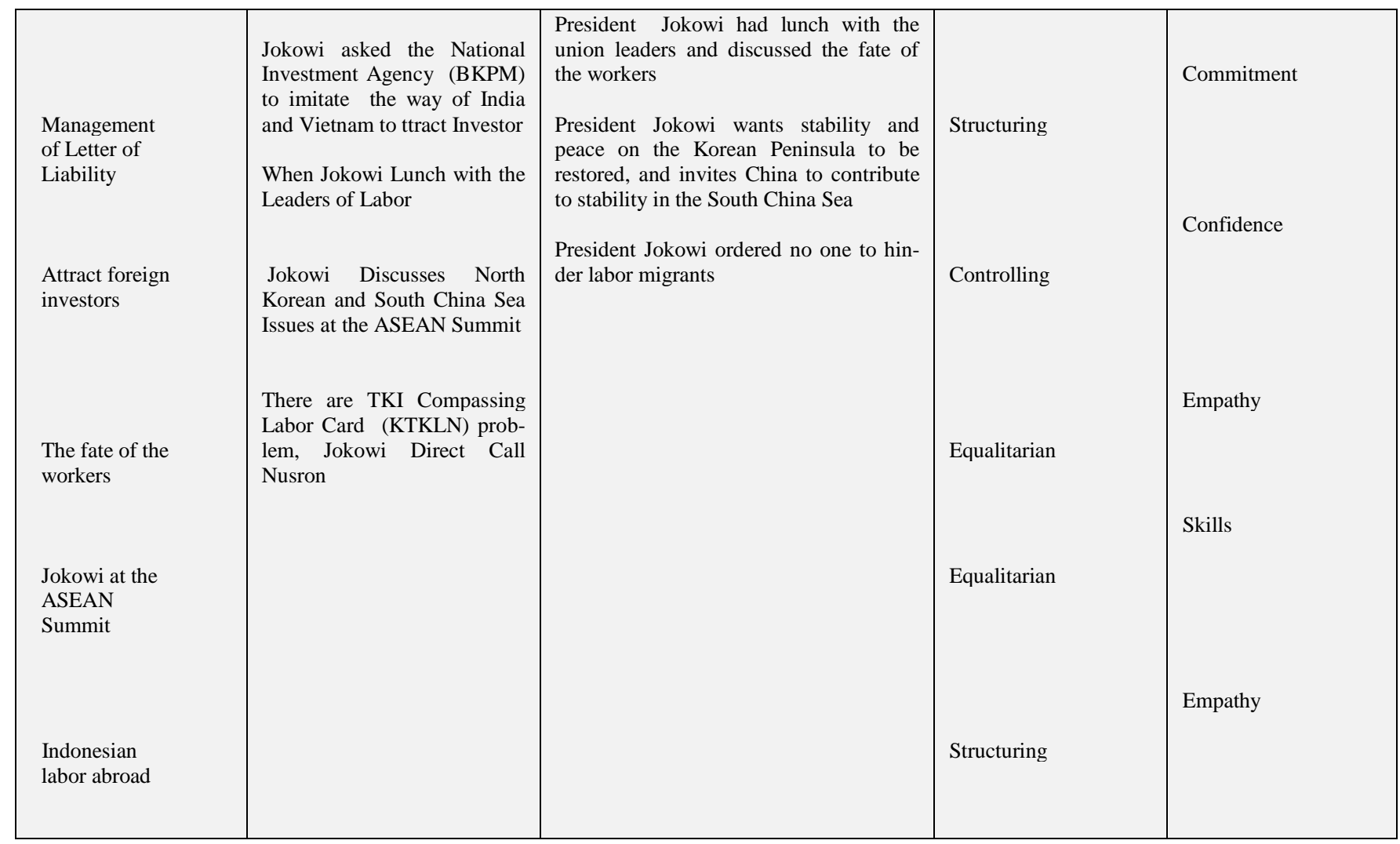

Based on the above table which is a summary of research results, can be seen the communication style of President Jokowi is often used in policy making is controlling style. It can be understood that as president in policy making in various situations Jokowi circumstances should be able to control the situation, where it is manifested in communicating. However, in addition to the controlling style, Jokowi also uses another style of communication that is an egalitarian style where Jokowi give others the opportunity to communicate equally with him, and Jokowi can express an opinion that shows that Indonesia can play at international level. Jokowi also often uses structuring style, when communicating the policy he has set for the implementation of the apparatus underneath. The Dynamic style is used by Jokowi when he changes the use of words in his statement by taking into account the circumstances when answering questions about TNI involvement in the effort to defeat the government of President Jokowi, he can give a joking answer. Jokowi also uses withdrawal style that there is a reluctance to communicate. This style of communication is used when Jokowi must respond to policies that can not be resolved, suppose cases of human rights violations.

From the result of research about communication competency owned by Jokowi based on communication done in decision making obtained that Jokowi has the elements of competence in communicating, which include; commitment and confidence, empathy, flexibility, sensibility, and consequence. Most of Jokowi's communication styles are controlling style, which means they already have the competence of confident and committed attitude, for example in the investment issue of Saudi Arabia, Jokowi believes Saudi Arabia will provide greater investment if legal certainty can be improved in Indonesia. Competence of commitment can be seen in the issue of letters of liability of civil servants, Jokowi committed that the completion of letters of liability only through two procedures. Empathy competence can be seen when Jokowi has lunch with labor representatives, Jokowi can empathize with the fate of the workers. The flexibility competence can be seen when Jokowi responds to the results of a foreign journalist's investigation of TNI involvement in the effort to defeat the government of President Jokowi, he simply replied to confirm it to the author, the answer to avoid the polemic and the growing issue in the wild. Seen that Jokowi can adjust situations where the given statements can ease an issue. Competence sensitivity consequences can be seen on human rights issues, although the communication made by Jokowi in the form of non-verbal, that is his unwillingness to meet the families of victims of human rights violations, what Jokowi have done contain the consequences of dissatisfaction of a group against the policy it took. Skill competencies can be seen when Jokowi gives a statement about the Korean peninsula and The South China Sea at the ASEAN Summit, Jokowi demonstrates the ability that he is able to communicate on an international level. So it can be seen that Jokowi has communication competence covering aspects of commitment and confidence, empathy, flexibility, a sensibility of consequence and skill.

\section{Conclusions}

Based on the results can be concluded that the communication style of Jokowi in communicating especially in policy making is controlling style, although in some situations also use other communication styles; namely structuring style, equalitarian style and also withdrawal style. Controlling styles are used when communicating the issue of electronic identity card corruption, ministerial work targets, the focus of Indonesian development, the organization of the Asian Games, and attracting foreign investors. Structuring styles are used when communicating on issues of easy investment, priority budgeting, overseas employment, and letters of liability of civil servant. The Equalitarian style is used when communicating about Saudi Arabia investment issues, the fate of workers, and the results of investigations of foreign journalists. Withdrawal style is used when communicating with human rights victims despite its non-verbal communication form.

Based on the analysis of Jokowi's communication in conveying his policy, Jokowi has communication competencies covering aspects of commitment and confidence, empathy, flexibility, a sensibility of consequence. Aspects of confidence can be seen when communicating on Saudi Arabia investment issues, facilitating investment, and organizing the Asian Games. Aspects of commitment can be seen when communicating on the issue of electronic identity card corruption, budgeting of civil servants, and settlement of letters of liability. Aspects of a sensitivity of consequenc- 
es can be seen when communicating on the issue of victims of human rights violations, and ministerial work targets. Aspect empathy can be seen when communicating about the fate of workers and labor abroad. Aspects of skills can be seen when Jokowi issued a statement at the ASEAN Summit.

\section{Acknowledgement}

This research work is supported by DIPA Direktorat Jenderal Penguatan Riset dan Pengembangan, Kementrian Riset, Teknologi, dan Pendidikan Tinggi Indonesia and UPN "Veteran" Jakarta.

\section{References}

[1] Arifin, B., \& Rani., A. (2000). Prinsip-prinsip analisis wacana. Departemen Pendidikan Nasional, Direktorat Jenderal Pendidikan Tinggi, Direktorat Pembinaan Penelitian dan Pengabdian Pada Masyarakat.

[2] Asma, A. (1996). Going Glocal : Cultural dimensions in Malaysian Management. Kuala Lumpur: Malaysian Institute of Management.

[3] Beatty, M. J., \& McCroskey, J. C. (1997). It's in our nature: Verbal aggressiveness as temperamental expression. Communication Quarterly, 45(4), 446-460. https://doi.org/10.1080/01463379709370076

[4] Burgoon, J. K , Buller, D. B., \& Guerrero, L. K. (1995). Interpersonal deception: IX. Effects of social skill and nonverbal communication on deception success and detection accuracy. Journal of Language and Social Psychology 14, 14(3), 289-311. https://doi.org/10.1177/07399863870092005

[5] Choon, Mooi, C. (2004). The Malaysian Communication Competence Construct. Journal of Intercultural Communication Research, 33.

[6] Cooley, R. E., \& Roach, D. A. (1984). A Conceptual Framework In R. N. Bostrom (Ed.), Competence in communication: A multidisciplinary approach (pp. 11-32). Beverly Hills, CA: SAGE.

[7] Gudykunst, Ting-Toomey, S., \& Chua, E. (1988). Culture and Interpersonal Communication. Newbury Park, CA: Sage Publications.

[8] Hall, E. T., \& Hall, M. R. (2000). Understanding Cultural Differences: Germans, French, and Americans. Yarmouth, ME: Intercultural Press.

[9] Hariyana. (2009). Komunikasi Dalam Organisasi. In Makalah Fakultas Ilmu Sosial dan Politik Universitas Indonesia.

[10] Jufri. (2008). Analisis Wacana Kritis. Makassar: Badan Penerbit UNM.

[11] Lailawati, M. S. (2008). Communication Competence: A Malaysia Perspective. Human Communication, 11(3), 303-311.

[12] Murphy, M. (2015). Which Of These 4 Communication Styles Are You?

[13] Richard, D. R. (2011). Communicative Competence and Interpersonal Control. In J. A. K. M. L. \& Daly (Ed.), Handbook of Interpersonal Communication (2nd ed). Thousand Oaks, CA: SAGE.

[14] Sanchez-Burks, J., Lee, F., Choi, I., Nisbett, R., Zhao, S., \& Koo, J. (2003). Conversing across cultures: East-West communication styles in work and nonwork contexts. Journal of Personality and Social Psychology, 85(2), 363-372. https://doi.org/10.1037/00223514.85.2.363

[15] Spitzberg, B. H., \& Cupach, W. R. (1984). Interpersonal communication competence. Beverly Hills, CA: SAGE.

[16] Spitzberg, B. H., \& Cupach, W. R. (2002). Interpersonal skills Handbook of Interpersonal Communication, 3, 564-611.

[17] Stogdill, Ralph; Coons, A. E. (1958). No Title. Review: Leadership Behavior: Its Description and Measurement, Vol 3, 271-273. https://doi.org/10.2307/2391024

[18] Sumarlam. (2009). Analisis Wacana. Surakarta: Pustaka Cakra.

[19] Widjaja, A. W. (2000). Ilmu Komunikasi. Jakarta: Bina Aksara.

[20] Wilson, S. R., \& Sabee, C. M. (2003). Explicating communicative competence as a theoretical term. In J. O. Greene \& B. R. Burleson (Eds.), Handbook of communication and social interaction skills (pp. 3-50). Mahwah, NJ: Lawrence Erlbaum.

[21] Wiseman, R. L. (2002). Intercultural communication competence. Thousand Oaks, CA: SAGE.

[22] Sanchez-Burks J, Lee F, Choi I, Nisbett R, Zhao S, Koo J. Conversing across cultures: East-West communication styles in work and nonwork contexts. Journal of Personality and Social Psychology. 2003;85(2):363-72.

[23] Hall ET, Hall MR. Understanding Cultural Differences: Germans, French, and Americans. Yarmouth: Intercultural Press; 2000.
[24] Gudykunst, Ting-Toomey S, Chua E. Culture and Interpersonal Communication. Newbury Park: Sage Publications; 1988. 280- p.

[25] Choon MC. The Malaysian Communication Competence Construct. Journal of Intercultural Communication Research. 2004;33.

[26] Lailawati MS. Communication Competence: A Malaysia Perspective. Human Communication. 2008;11(3):303-11.

[27] Asma A. Going Glocal : Cultural dimensions in Malaysian Management. Kuala Lumpur: Malaysian Institute of Management; 1996.

[28] Jufri. Analisis Wacana Kritis. Makassar: Badan Penerbit UNM; 2008.

[29] Arifin B, Rani A. Prinsip-prinsip analisis wacana: Departemen Pendidikan Nasional, Direktorat Jenderal Pendidikan Tinggi, Direktorat Pembinaan Penelitian dan Pengabdian Pada Masyarakat; 2000. 228-p

[30] Sumarlam. Analisis Wacana. Surakarta: Pustaka Cakra; 2009.

[31] Widjaja AW. Ilmu Komunikasi. Jakarta: Bina Aksara; 2000.

[32] Hariyana. Komunikasi Dalam Organisasi. 2009.

[33] Stogdill R, Coons AE. No Title. Review: Leadership Behavior: Its Description and Measurement. 1958; Vol 3:271-3.

[34] Murphy M. Which Of These 4 Communication Styles Are You? 2015.

[35] Cooley RE, Roach DA. A Conceptual Framework. In: Bostrom RN, editor. Beverly Hills: SAGE; 1984. p. 11-32.

[36] Wiseman RL. Intercultural communication competence. Thousand Oaks: SAGE; 2002. 207-24 p.

[37] Burgoon JKBDB, Guerrero LK. Interpersonal deception: IX. Effects of social skill and nonverbal communication on deception success and detection accuracy. Journal of Language and Social Psychology 14. 1995;14(3):289-311.

[38] Beatty MJ, McCroskey JC. It's in our nature: Verbal aggressiveness as temperamental expression. Communication Quarterly. 1997;45(4):446-60

[39] Spitzberg BH, Cupach WR. Interpersonal skills. Handbook of interpersonal communication. 2002;3:564-611.

[40] Wilson SR, Sabee CM. Explicating communicative competence as a theoretical term. In: Greene JO, Burleson BR, editors. Mahwah Lawrence Erlbaum; 2003. p. 3-50.

[41] Richard DR. Communicative Competence and Interpersonal Control. In: M L, Daly JAK, editors. Thousand Oaks: SAGE; 2011. 